\title{
Nutritional content, performance and ratooning ability of four sorghum genotypes
}

\author{
Harmini Harmini*, Achmad Fanindi, Endang Sutedi, Iwan Herdiawan, and Sajimin Sajimin \\ Indonesian Research Institute for Animal Production, Ciawi 16002, Indonesia
}

\begin{abstract}
Sorghum is a grain plant that is a source of food, biofuel and feed, which can be produced using the techniques of ratoon cultivation. The objective of this study is to assess the nutrition content, the performance of the four sorghum genotypes and the vegetative characteristics of the sorghum ratoon. The research was carried out from December 2020 to July 2021 at the Ciawi Research Garden, the Livestock Research Institute. The study employed four treatments (genotype) and three replications of random block design. The range of protein content, crude fat crude fiber and ash in the four genotypes of sorghum was 7.91-9.30, 1.91-2.69, 33.41-37.57 and $8.25-9.11 \%$, respectively. Genotype significantly affected $\mathrm{P}<0.05$ on plant height, stem height, leaf width, internode length, flag leaf width and fresh weight, but not significantly different $\mathrm{P}>0.05$ on leaf length, stem diameter and flag leaf length on the main plant. Genotype had no significant effect $(\mathrm{P}>0.05)$ on plant height, number of tillers, leaf length, leaf width and fresh weight of ratoons. It was concluded that the ability of ratoon in sorghum was not affected by the genotype of sorghum.
\end{abstract}

\section{Introduction}

Sorghum is a cereal grain with multiple uses, including food, animal feed, and fuel. As a result of its high nutritional value and ability to grow on dry land, this plant has the potential to be developed as a ruminant feed source [1]. One potential crop to develop with the ratoon system is sorghum. A few reasons for using the ratoon system to cultivate plants include: $30 \%$ regrowth, $20 \%$ labor savings, excessive vegetative regrowth, and disease potential (18 percent ) [2]. The dry matter production, drought tolerance, and better regrowth after grazing or cutting of sorghum are more promising when compared to the other forages [3]. The Agency for Agricultural Research and Development has developed several superior varieties of sorghum. Super sorghum 1 is the result of improving the White Hamu Watar population from the Cereal Research Institute's germplasm collection, with characteristics of aphis resistance, anthracnose resistance, leaf rust and leaf blight, suitable for dry land and dry climates and environmental adaptation [4]. While sorghum super 2 is an improvement over the 15021 strain from ICRISAT, the characteristics of producing ratoon [4]. Sorghum bioguma, on the other hand, is the product of 59 Gy gamma rays and in vitro culture on

\footnotetext{
* Corresponding author: hmini2011@gmail.com
} 
parents of the Numbu variety [5], Numbu, on the other hand, is the name of the native sorghum variety.

Ratoons are used in the cultivation of sorghum as one of the methods. Ratoons are raised by harvesting the first season's crop, allowing it to regrow, and then cultivating it like sorghum grown from seed. The genotype has a significant impact on the main plant's vegetative, reproductive, physiology, the ratoon's ability, and the vegetative character. Plant height, stem diameter, wet and dry stover weight, harvest age, and harvest index were found to be significantly correlated with the ability to ratoon. Significantly correlated with ratoon plant performance were the main plant's height, total leaf chlorophyll, wet and dry stover weight, panicle weight, seed weight per panicle, 1,000 seed weight, harvest index, and transpiration rate. Scientific studies have been done on the effects of cultivating ratoons on crop yield, sugar production, and pest attack [6], evaluation of sweet sorghum growth and yield at various spacings [7], evaluation of sweet sorghum genotypes with high biomass production and high ratoon capacity. We conducted a study to determine the productivity of ratoons from four types of sorghum consisting of one national variety and three breeding varieties to be developed as forage for livestock based on the information above

\section{Materials and methods}

\subsection{Material}

This research was carried out in the experimental garden of Indonesian Research Institute for Animal Production (IRIAP), from December 2020 to June 2021. The materials used were Sorghum varieties Super 1, Super 2, Bioguma and Numbu which are the result of breeding at the Agricultural Research and Development Agency.

\subsection{Method}

The experimental design used was a one-factor randomized block design, namely genotype with 4 replications. Sorghum is planted with a spacing of $50 \mathrm{~cm}$, on a plot of $2 \mathrm{~m} \mathrm{x} 1 \mathrm{~m}$, with planting without tillage. Sorghum plants grown from seeds are called primary crops. Sorghum is ratified after harvesting by cutting the main stem and leaving one segment from the soil surface, approximately 5 to $10 \mathrm{~cm}$ from planting. Ratoon plants are plants that grow from the remaining internodes of other plants.

The variable observed in the main plant was the vegetative character. Vegetative characters for the main plant consisted of plant height, stem height, leaf length, leaf width, internode length, stem diameter, flag leaf length, flag leaf width, fresh weight, while for ratoon included plant height, number of tillers, leaf length, width leaves and fresh weight. Analysis of nutrient content in forage sorghum includes water, fat, and crude and ash content by gravimetric method, while protein and energy content by calorimeter. The data were analyzed by analysis of variance and if there was a significant difference, Duncan further tested it Steel [8] with SPSS 16.

\section{Results and discussion}

\subsection{The nutritional content of forage sorghum}

The nutritional content of the main forage sorghum plant can be seen in Table 1. Based on Table 1 the four types of sorghum have almost the same crude protein (CP) content from 7.91 
to $9.30 \%$, with an average CP content of $8.38 \%$, where Super 1 has the highest CP content. Crude fiber (CF) content in the range of 33.41 to $37.57 \%$, and an average of $35.93 \%$. crude fat (CFat) content, 1.91 to $2.69 \%$ and an average of $2.28 \%$, energy content from 3958 to 40 $45 \mathrm{kcal} \mathrm{kg}-1$ with an average of $3988 \mathrm{kcal} \mathrm{kg}-1$, and ash content from 8.25 to $9.11 \%$ with an average of $8.77 \%$.

Research result Koten et al. [9] in local sorghum Rote got slightly different results, the content of CP, ash, CFat and CF were 9.90; 11.45; 2.7 and $20.32 \%$, respectively. Local varieties of sorghum Rote were added, which were harvested at the age of 90 days with a dose of $100 \mathrm{~kg}$ ha-1 urea fertilizer, producing the highest Dry Matter (DM), Organic Matter $(\mathrm{OM})$ and $\mathrm{CP}[10]$. Sorghum is rich in carbohydrates, micronutrients, rich in soluble fiber and a source of nutraceuticals such as phenols and tannins [11]. Plant density affects the accumulation of dry matter in sorghum ratoon, the higher the density, the lower the dry matter content [12]. There is a difference in biomass quality between the main crop and ratoon [13].

Table 1. Simply character of tilapia fish skin as a tannery material [8-9]

\begin{tabular}{|l|c|c|c|c|c|}
\hline \multicolumn{1}{|c|}{ Varietas } & $\begin{array}{c}\text { Crude } \\
\text { Protein (\%) }\end{array}$ & $\begin{array}{c}\text { Crude Fat } \\
\mathbf{( \% )}\end{array}$ & $\begin{array}{c}\text { Energi (kcal } \\
\left.\mathbf{k g}^{-1}\right)\end{array}$ & $\begin{array}{c}\text { Crude Fiber } \\
\mathbf{( \% )}\end{array}$ & Ash (\%) \\
\hline Super 1 & 9.30 & 2.28 & 3958 & 33.41 & 8.98 \\
\hline Super 2 & 8.01 & 1.91 & 3969 & 36.30 & 9.11 \\
\hline Bioguma & 7.91 & 2.25 & 3980 & 37.57 & 8.77 \\
\hline Numbu & 8.31 & 2.69 & 4045 & 36.46 & 8.25 \\
\hline Average & 8.38 & 2.28 & 3988 & 35.93 & 8.77 \\
\hline
\end{tabular}

In this study, we investigated the using of fresh palm oil and used palm oil as a fat liquoring agent in the tannery of tilapia skin. The study aims to find out the physical quality of leather through the using of fresh and used palm oil as fatliquoring agent in the vegetable tannery process. The physical quality of tilapia leather was observed and evaluated by examining parameters of tensile strength, elongation, and shrinkage temperature.

\subsection{Effect of genotype on main plant performance}

Based on Tables 2 and 3, it can be seen that plant height, stem height, leaf width, internode length, leaf width and fresh weight were not significantly different from flag leaf length. Sorghum Super 1 has the highest vegetative growth compared to other varieties. In Table 4 it can be seen that for sorghum ratoon plant Super 1 had the highest plant height, Super 2 had the highest number of tillers and the highest leaf length, Numba had the highest leaf width and highest fresh weight. Genotype significantly affected the performance of the main plant and ratoon, ratoon production in sorghum reached $48.9-65.7 \%$ of the main crop production [14]. One indicator of sorghum production as forage is plant height, stem diameter and number of leaves. Sorghum varieties affect plant height, stem diameter, number of leaves and nutritional quality (ash content, CF and CP) [15]. Stem diameter days of 50\% flowering had a significant correlation and high positive direct effect with panicle weight [16]. The average fresh weight of sorghum ratoon decreased by $83.33 \%$. This result is different from the results of research [17] which states that the productivity of ratoon sorghum will be higher if planted in the rainy season. Crops and ratoons differ in their ability to accumulate and allocate dry matter between forage and grain biomass [18]. Differences in sorghum varieties affect the growth and yield of sorghum ratoon except for stem diameter and wet stover weight [19]. Ratoon production is $30 \%$ of the main crop in the dry season [20]. The height of the ratoon plant is lower than the main crop, this is different from Vinutha et al. [13]. The average plant height was greater in the ratoon crop than in the main crop. Season affects the height of ratoon 
sorghum, where in winter it is higher than summer [21]. Ratooning is a cultural practice to stimulate regrowth of the basal or lower epigeal buds after removal of the photo-synthetically active material.

Table 2. Vegetative growth of four varieties of sorghum

\begin{tabular}{|l|c|c|c|c|c|}
\hline \multicolumn{1}{|c|}{ Variety } & $\begin{array}{c}\text { Height of } \\
\text { plants (cm) }\end{array}$ & $\begin{array}{c}\text { Stem height } \\
(\mathbf{c m})\end{array}$ & $\begin{array}{c}\text { Leaf length } \\
(\mathbf{c m})\end{array}$ & $\begin{array}{c}\text { Leaf width } \\
(\mathbf{c m})\end{array}$ & $\begin{array}{c}\text { Segment } \\
\text { length }(\mathbf{c m})\end{array}$ \\
\hline Super 1 & $319.62^{\mathrm{a}}$ & $267.82^{\mathrm{a}}$ & 72.72 & $7.47^{\mathrm{a}}$ & $31.12^{\mathrm{a}}$ \\
\hline Super 2 & $275.81^{\mathrm{b}}$ & $242.43^{\mathrm{a}}$ & 83.29 & $6.12^{\mathrm{b}}$ & $29.19^{\mathrm{ab}}$ \\
\hline Bioguna & $206.33^{\mathrm{c}}$ & $195.08^{\mathrm{b}}$ & 75.94 & $5.91^{\mathrm{b}}$ & $22.10^{\mathrm{bc}}$ \\
\hline Numba & $204.37^{\mathrm{c}}$ & $180.65^{\mathrm{b}}$ & 72.72 & $5.50^{\mathrm{b}}$ & $25.03^{\mathrm{c}}$ \\
\hline Average & 251.53 & 221.49 & 76.17 & 6.25 & 26.86 \\
\hline
\end{tabular}

Note: Numbers followed by different letters in the same column show significantly different effects $(\mathrm{P}<0.05)$

Table 3. Stem diameter, flag leaf length, flag leaf width, total fresh weight

\begin{tabular}{|l|c|c|c|c|}
\hline \multicolumn{1}{|c|}{ Variety } & $\begin{array}{c}\text { Stem diameter } \\
(\mathbf{m m})\end{array}$ & $\begin{array}{c}\text { flag leaf length } \\
(\mathbf{m m})\end{array}$ & $\begin{array}{c}\text { flag leaf width } \\
(\mathbf{m m})\end{array}$ & $\begin{array}{c}\text { total fresh } \\
\text { weight(gram) }\end{array}$ \\
\hline Super 1 & 1289.30 & 43.54 & $6.11^{\mathrm{a}}$ & $338.73^{\mathrm{a}}$ \\
\hline Super 2 & 1115.22 & 36.21 & $4.82^{\mathrm{b}}$ & $192.86^{\mathrm{b}}$ \\
\hline Bioguna & 969.90 & 33.71 & $5.23^{\mathrm{b}}$ & $177.71^{\mathrm{b}}$ \\
\hline Numba & 969.74 & 32.18 & $4.92^{\mathrm{b}}$ & $158.71^{\mathrm{b}}$ \\
\hline Average & 1086.04 & 36.41 & 5.27 & 217.00 \\
\hline
\end{tabular}

Note: Numbers followed by different letters in the same column show significantly different effects $(\mathrm{P}<0.05)$

Table 4. Ratoon ability and vegetative character of ratoon plant four genotypes of sorghum

\begin{tabular}{|l|c|c|c|c|c|}
\hline \multicolumn{1}{|c|}{ Variety } & $\begin{array}{c}\text { Plant height } \\
\text { (cm) }\end{array}$ & $\begin{array}{c}\text { Number of } \\
\text { tiller }\end{array}$ & $\begin{array}{c}\text { Leaf length } \\
\mathbf{( c m )}\end{array}$ & $\begin{array}{c}\text { Leaf width } \\
\mathbf{( c m )}\end{array}$ & $\begin{array}{c}\text { total fresh } \\
\text { weight } \\
\text { (gram) }\end{array}$ \\
\hline Super 1 & 111.05 & 2.09 & 50.59 & 2.89 & 38.00 \\
\hline Super 2 & 101.80 & 2.36 & 55.48 & 2.89 & 27.60 \\
\hline Bioguna & 99.99 & 1.80 & 49.02 & 3.093 & 23.36 \\
\hline Numba & 94.35 & 1.62 & 43.88 & 3.11 & 43.03 \\
\hline Average & 101.80 & 1.91 & 49.74 & 2.99 & 33.00 \\
\hline
\end{tabular}




\section{Conclusion}

Sorghum has the potential to be developed as an animal feed crop. One of the cultivations is by developing ratoon sorghum. The type of variety has an effect on the ability of the maturation of sorghum. The Numba ratoon variety produced the highest fresh weight compared to the Super 1, Super 2 and Bioguna varieties.

\section{References}

1. H. Harmini, Livest. Anim. Res. 19 (2021)

2. P. Roge, S Snap, M. N. Kakwera, L. Mungai, I. Jambo, B. Peter, Agron. Sustain. Dev. 36, 1-18 (2016)

3. A. R. S. Shakeri, E. Y. Emam, S. A. Tabatabaei, Intl. J. Plant Prod. 11 (2017)

4. Badan Penelitian dan Pengembangan Pertanian, Kementrian Pertanian, Jakarta, Indonesia (2018)

5. E. Lestari, I. Dewi, R. Yunita, A. Nur, Azrai, K. Syahruddin, Bioguma 1 Agritan. (2019)

6. K. Wilson, University of Greenwich. London, (2011)

7. D. Puspitasari, D. Kastono, S. Waluyo, Vegetalika 1 (2013)

8. R. Steel, J Torrie, Prinsip dan Prosedur Statistika Suatu Pendekatan Biometrik (Gramedia, Jakarta, Indonesia, 1995)

9. B. B. Koten, R. D. Soetrisno, N. Ngadiyono, B. Suwignyo, Buletin Peternakan 36 (2012)

10. B. B. Koten, R. D. Soetrisno, N. Ngadiyono, B. Soewignyo, Jurnal Pastura 3 (2014)

11. P. Pontieri, L. Del Giudice, Encycl. Food Heal. 2 (2016).

12. B. Ferdian, S. Sunyoto, A. Karyanto, M. Kamal, Jurnal Agrotek Tropika 3 (2015)

13. K. S. Vinutha, G. S. Anil Kumar, M. Blümmel, P. Srinivasa Rao, Trop. GrasslandsForrajes Trop 5, 40-49 (2017).

14. M. G. TMeliala, Trikoesoemaningtyas, D. Sopandie, Jurnal Agronomi Indonesia 45 (2017)

15. Hajar H, IPB (2020)

16. S. E. Ardiyanti, D. Sopandie, D. Wirnas, Trikoesoemaningtyas, IOP Conference Series: Earth and Environmental Science 399 (2019)

17. N. Tsuchihashi, Y. Goto, Plant Prod. Sci. 11 (2008)

18. T. J. Gerik, W. D. Rosenthal, W. F. Seavey, F. Crop. Res. 23 (1990)

19. G. D. Cahyo, K. F. Hidayat, S. Sunyoto, M. Kamal, Jurnal Agrotek Tropika 2 (2014)

20. H. Gnanagobal, J. Sinniah, Trop. Grasslands-Forrajes Trop. 6 (2018)

21. S. A. Hassan, M. I. Mohammed, S. O. Yagoub, J. Plant Breed. Crop Sci. 7 (2015) 